\title{
Portrait of the East of England
}

By Susie Corke and Jenny Wood, Office for National Statistics

\section{Key points}

The East of England Region:

- is one of the larger regions in terms of area and population

- is projected to have a higher population growth than most other regions over the next 20 years with a particularly large increase in the older age group

- is one of the largest regions in terms of its share of jobs and has a high level of labour productivity

- has the highest expenditure on research and development by businesses in the UK

- has a below average proportion of residents with high level qualifications

- has a relatively low level of deprivation overall but has a few sub regional areas with higher deprivation.

Overall the residents of the East of England:

- have sustained comparatively high level of employment and low unemployment rates

- earn above the national average when in employment

- recycle more household waste than any other region and produce below average amounts of carbon dioxide

- live in a region with the lowest recorded crime rate in England and Wales.

Jen Wood is Regional Statistician for the East of England Susie Corke is Regional Analyst

Tel: 01223484549

Mobile: 07788415324

Email: susan.corke@ons.gsi.gov.uk

\section{Introduction}

The East of England region shares its borders with London, the South East and the East Midlands. It also has an extensive coast line, 121 kilometres of which are defined as heritage coast.

At around 19,100 square $\mathrm{km}$ it is the second largest English region, below only the South West. It is larger than Northern Ireland but smaller than Scotland and Wales. The region covers 15 per cent of the total area of England and 8 per cent of the UK.

Administratively, the East of England contained six counties in 2008: Bedfordshire, Cambridgeshire, Essex, Hertfordshire, Norfolk and Suffolk, and four unitary authorities, Luton, Peterborough, Southend-on-Sea and Thurrock. There were 44 local authority districts contained within the counties in the region (see Map 5.2).

The region is generally low lying compared with other parts of the country and there are no mountainous areas, although the Chiltern Hills extend into the south west (see Map 5.1). Notable geographic features include the Fens in the central northern part of the region extending into the East Midlands, and the Norfolk and Suffolk Broads. The region contains several large forests including Thetford Forest and Epping Forest, and many smaller woods. These areas attract holiday makers and day visitors.

East of England receives a very low amount of rainfall compared with other parts of the UK and some parts of Essex and East Anglia are classified as semi-arid due to exceptionally low rainfall.

Large expanses of arable land are characteristic of the region. Crops range from high intensity cereal production, requiring little labour, to labour intensive vegetable production in the Fens. Sugar beet is also grown in large quantities with much of the UK's sugar production taking place in Suffolk and Norfolk. Twenty per cent of all cereal farms in the UK were in the East of England in 2006. Around 27 per cent of the farm holdings in the region were 0.5 square $\mathrm{km}$ or above, the second highest percentage after the North East. There is one National Park covering the Norfolk Broads which is around 300 square $\mathrm{km}$ in area and makes up 2 per cent of the region. (Online tables $3.22,3.23$ and 5.8) 


\section{Map 5.1 East of England: physical features}
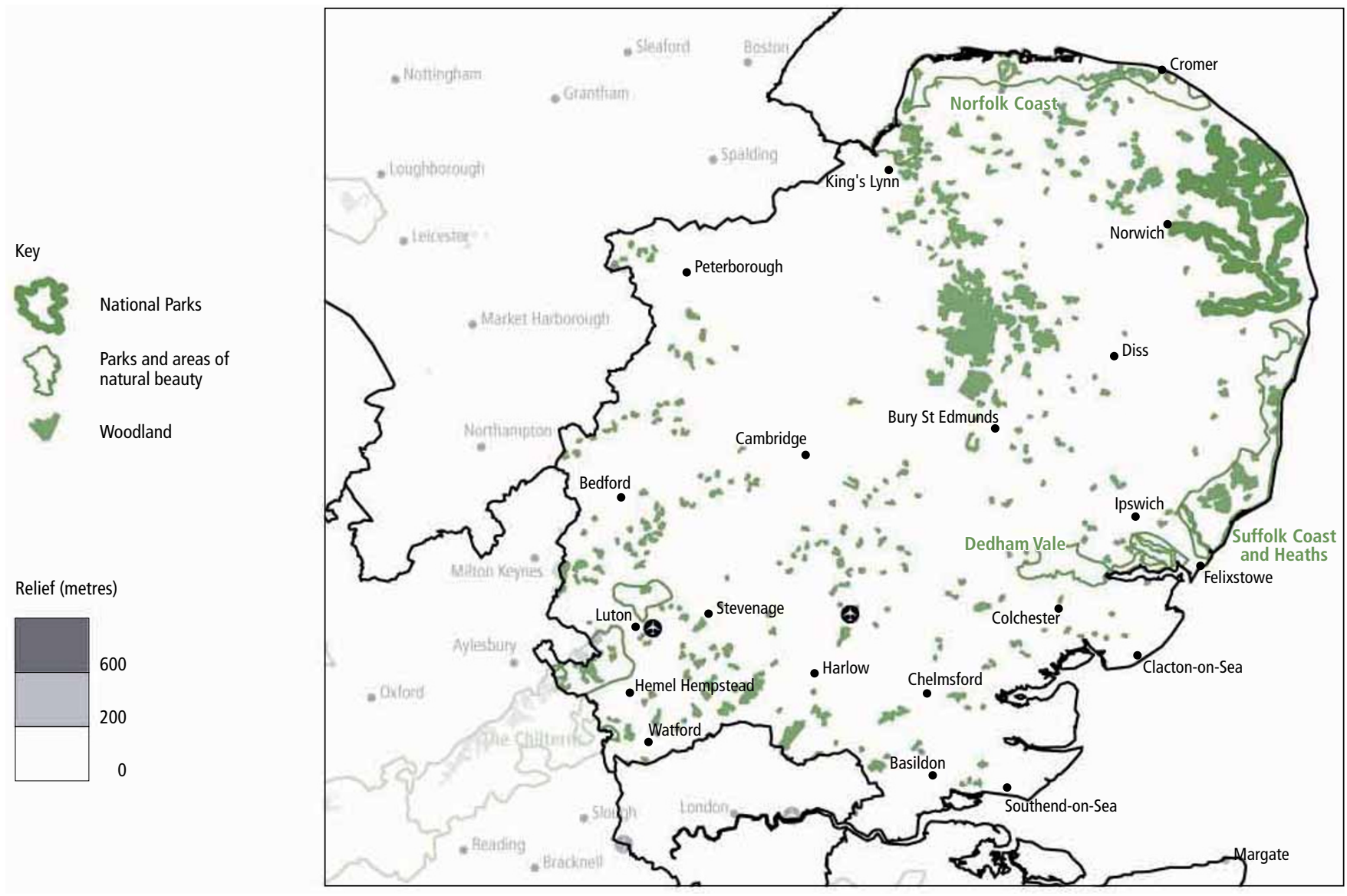

Large towns and cities in the region include Norwich, Cambridge, Peterborough, Stevenage, Ipswich, Colchester, Southend-on-Sea and Luton. Many towns have a direct train link to Central London and large numbers of workers commute to the city on a daily basis.

Two of the five international London airports are in East of England, at Luton and Stansted. London Stansted is the third largest UK airport in terms of passengers after London Heathrow and London Gatwick. The major sea ports of Felixstowe and Harwich are also in the region. Nearly 30 million tonnes of freight were handled through these ports in 2007. (Online tables 11.16 and 11.17)

The region is home to seven universities, including the University of Cambridge, and several other higher education establishments. The main employment sectors include business services, wholesale and retail and health and social care. Business services include research and development, which is a particular feature of the region, especially around Cambridge.

\section{Population}

The East of England had a population of 5.7 million in 2007, amounting to 9.3 per cent of the UK population. This is the fourth highest population of all regions in the UK after the South East (8.3 million), London (7.6 million) and the North West (6.9 million). (Online table 10.1)
The local authorities with the largest populations were Luton UA $(190,000)$ and Colchester in Essex (180,000). The local authorities with the smallest populations were Maldon in Essex $(62,000)$ and Forest Heath in Suffolk $(63,000)$. Seven other local authorities have populations of 150,000 or more. (Online table 1.1)

Population density in 2007 was 300 people per square km, above the UK average of 250 but below the England average of 390. However population density varies considerably below regional level. The density in local authorities in the region ranged from 100 people per square kilometre in Kings Lynn and West Norfolk and Breckland in Norfolk to 4,400 in Luton UA, which is the third most densely populated local authority outside London, below Portsmouth UA and Southampton UA both in the South East. London had a population density of 4,800 people per square $\mathrm{km}, 16$ times the density in the East of England.

Experimental population estimates for mid 2006 for Lower Level Super Output Areas (LSOAs) show that approximately 70 per cent of the region's population live in areas classed as urban over 10,000 population, and approximately 30 per cent in areas classed as towns or rural. (Figure 5.3 and Map 5.2)

The population increased by 54,500 between 2006 and 2007, an increase of 1.0 per cent. This region experienced one of the three largest percentage increases among the regions and countries of the UK, together with Northern Ireland and the South West (both around 1 per cent). The population of the UK increased by 0.6 per cent in this period. (Online table 10.8) 
Map 5.2 East of England: local or unitary authority, NUTS $2^{1}$ sub-regions and Rural and Urban Area Classification

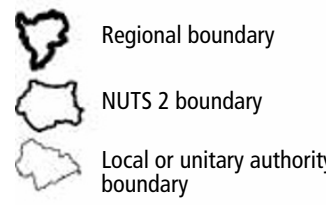

Rural and Urban Area Classification

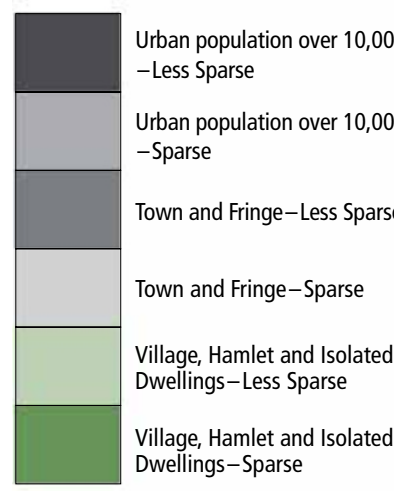

1 Great Yarmouth 14 Castle Point

2 Norwich 15 Southend-on-Sea

3 Cambridge

UA

4 Ipswich

5 Luton UA

6 South Bedfordshire

7 Stevenage

8 Welwyn Hatfield

9 Broxbourne

10 Harlow

11 Hertsmere

12 Watford

13 Three Rivers

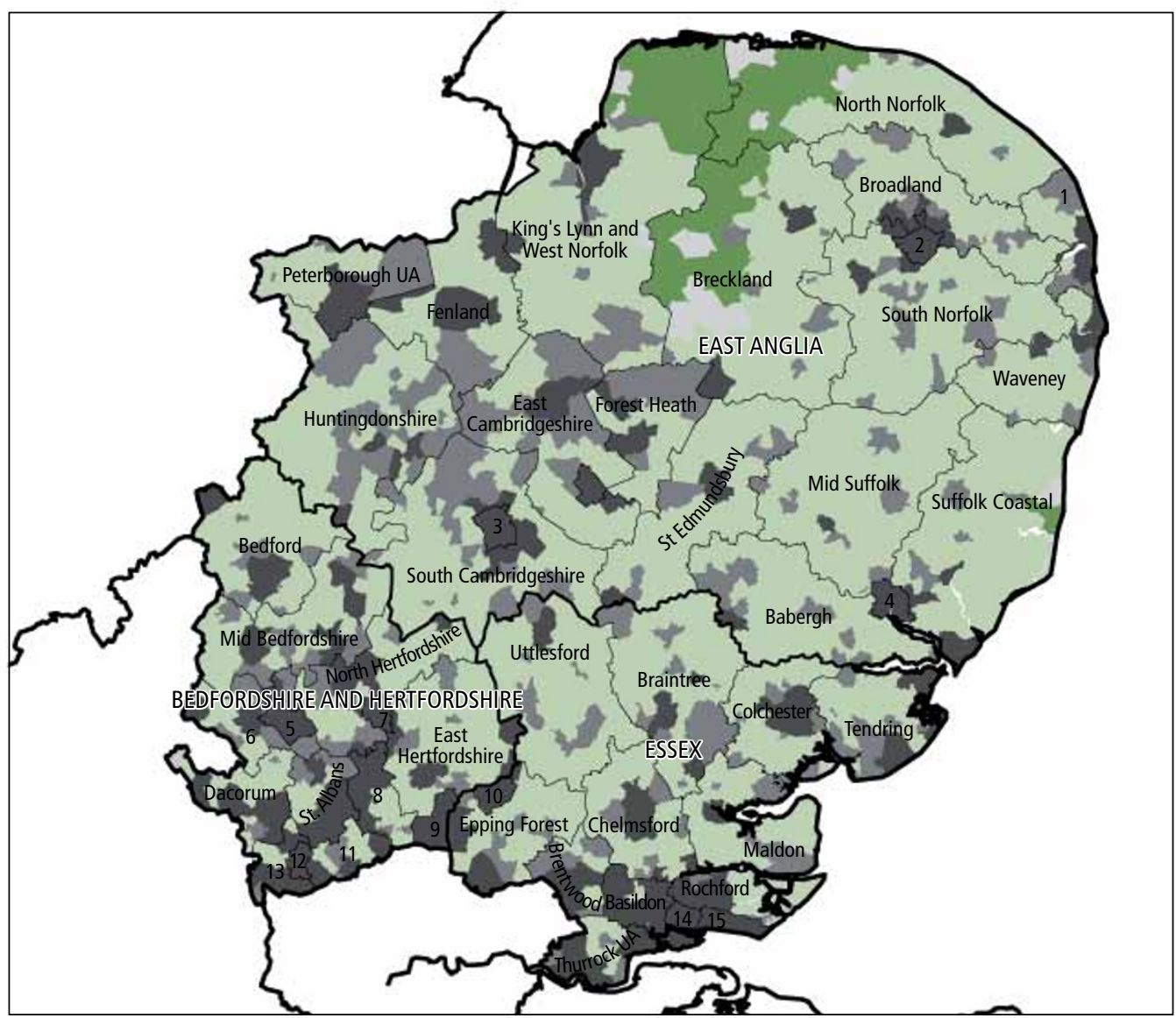

1 Nomenclature of Units for Territorial Statistics, level 2.

. 2 By Lower Layer Super Output Area.

Figure 5.4 demonstrates the large variation in population change between 2006 and 2007 at county and unitary authority level in the East of England. The local authority with the highest percentage population growth between 2006 and

\section{Figure 5.3 Population by Rural and Urban Area Classification, East of England, mid-2006}

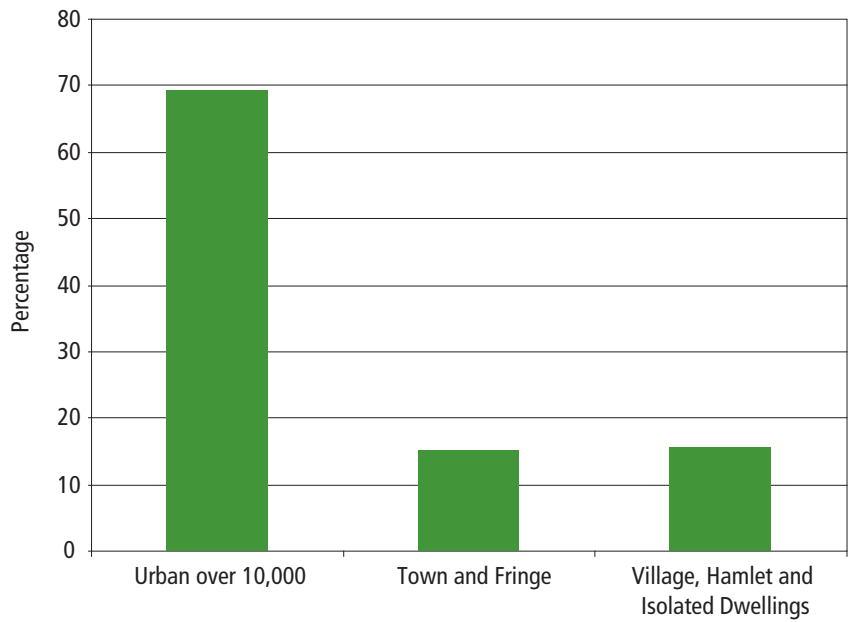

2007 was Colchester in Essex which increased by 2.7 per cent, 90 per cent of this growth was due to net migration.

Net migration and other change accounted for over two thirds of population growth in the East of England between 2006 and 2007, although there is significant variation within the region. In the UK as a whole net migration and other change accounted for just over half the total population growth.

Figure 5.5 shows net change per 10,000 residents from interregional and international migration by region for 2007 . The total inflow is greater than the total outflow for both interregional and international migration in the East of England. The net effect of migration was to increase the population in 2007 by about 88 people per 10,000 residents, which is the highest rate among the English regions. (Online table 10.6)

In terms of birth rates, the East of England (12.2 live births per 1,000 population in 2007) is lower than the average for the UK (12.7 per 1,000 population). This supports the comparatively low population increase due to natural change. Within the region in 2007, Luton had the highest birth rate (18.5) and North Norfolk (7.9) the lowest. (Online table 10.5 and 1.2). This measure does not take into account the number and proportion of women in childbearing age-groups within the 
Figure 5.4 Components of population change East of England, mid-2006 to mid-2007

Source: Office for National Statistics

population, or the varying age structures of women in different areas, which is why it is necessary to consider the total fertility rate.

The total fertility rate (TFR) was slightly higher at 1.94 births per woman, than the overall rate for the UK (1.90) in 2007. This measure standardises for the age distribution and number of women of childbearing age in an area to allow comparison between areas, and shows the number of children a woman would have if current fertility patterns persisted throughout her child-bearing life. Within the region, Luton and Peterborough had the highest TFR (2.45) and Cambridge had the lowest (1.43) (Online table 10.9) by county and unitary authority,

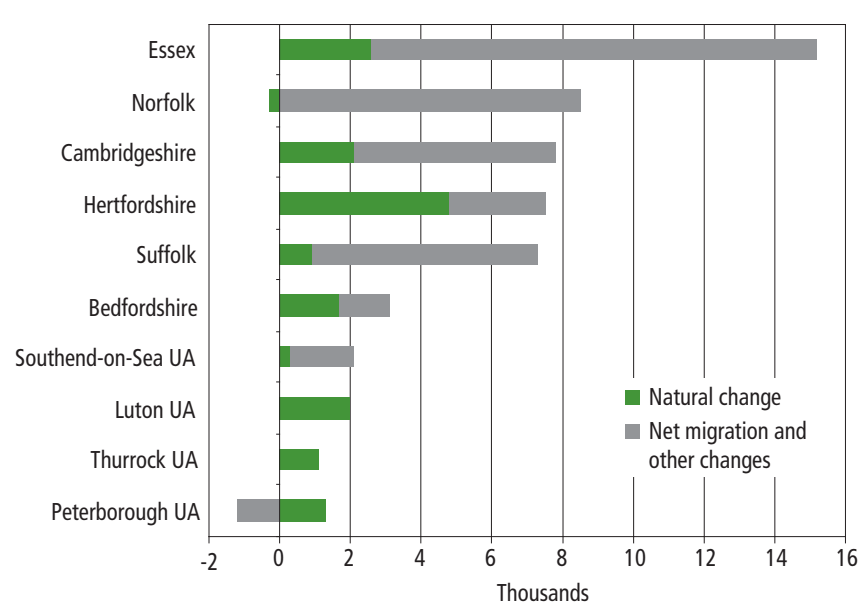

Over a longer period, between 2002 and 2007, the population of the East of England rose by 228,000, an increase of 4.2 per cent compared with 2.8 percent in the UK as a whole. No other region's population had a higher rate of increase in this period and only the East Midlands had an equal rate.

The 2006-based population projections indicate that the population of the East of England will reach 6.8 million by 2026, 20 per cent more than in 2006. This is the second largest projected increase of the English regions after the East Midlands. The population of England is projected to increase by 16 per cent in the same period.

Figure 5.6 shows that the age structure in the East of England in 2007 was broadly similar to the UK but with a lower proportion of young adults (aged 15 to 34) and a higher proportion approaching state pension age (women aged between 55 and 59, and men aged between 55 and 64). About 20 per cent of the population of the East of England were of state pension age, similar to the UK population (19 per cent), the difference mainly due to women aged 60 to 64 . Those of working age (aged 16 to state pension age) amounted to 61 per cent of the population of the East of England, similar to the 62 per cent in the UK population, since the differences in the younger and older working age groups largely cancel out. (Online table 10.2)

The number of older people is expected to grow at a greater rate than the total population. The population of those aged 65 and over in 2026 is projected to be 55 per cent higher than the 2006 population. This is the second largest increase of the English regions after the East Midlands and higher than the total projected 46 per cent rise in this age group in England.

Figure 5.6 Mid-year population estimates by 5 year age band and sex, East of England, 2007

Figure 5.5 Net migration per 10,000 residents by region, 2007

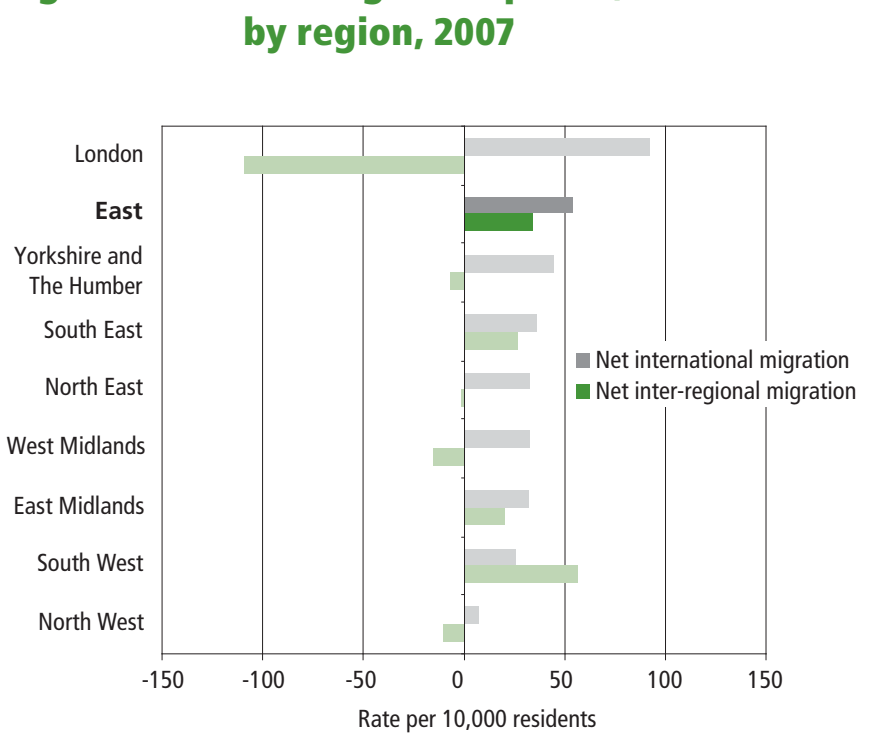

Source: National Health Service Central Register and International

Passenger Survey, Office for National Statistics; Home Office

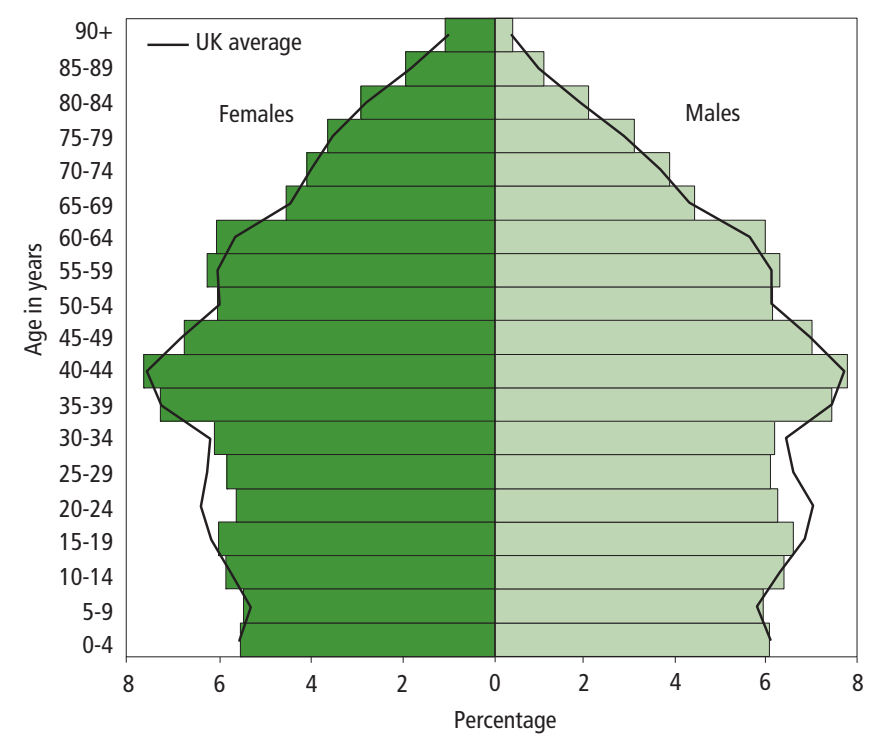

Source: Office for National Statistics 
The region was home to 8.6 per cent of England's population who do not class themselves as White British in 2006, according to experimental population estimates by ethnic group. (Online table 10.4)

An estimated 88 per cent of the population is made up of people classing themselves as White British. Although this is above the England average of 84 per cent only two regions (the West Midlands and London) have a lower percentage of White British population; the lower England average reflects the very low proportion of White British in London's population (58 per cent)

The largest non-White ethnic group in the region is Asian or Asian British who make up 3.3 per cent of the population compared with 5.5 per cent of the population of England. Of the local authorities, Luton had the highest proportion of nonWhite British residents at 40 per cent followed by Forest Heath (in Suffolk) with 29 per cent and Cambridge with 26 per cent. In Luton the largest ethnic group after White British is Asian (20 per cent of population), whereas in Forest Heath and Cambridge it is Other White (18 and 10 per cent respectively). Forest Heath has a USA military base and a small overall population. This could contribute to the high proportion of Other White population.

For the year ending March 2008, approximately 91 per cent of usual residents in the East of England were born in the UK; this is close to the UK average of 89 per cent. The variation in the proportion of UK-born residents at county and unitary authority level in the region is considerable, from 69 per cent in Luton to 94 per cent in Norfolk.

\section{Figure 5.7 Household estimates and projections' by household type, East of England, 2001 to 2026}

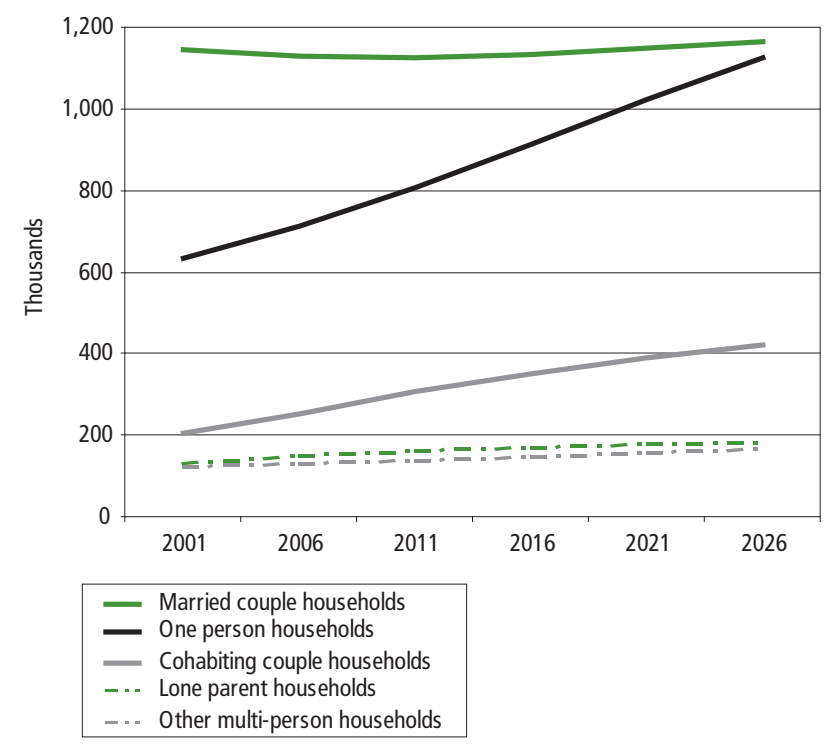

1 Projections are 2006-based.

Source: Communities and Local Government

\section{Households and housing}

There were an estimated 2.37 million households in the East of England in 2006. This was 11 per cent of the number of households in England. (Online table 10.15) Average household size was estimated at 2.33 people, which was close to the England average of 2.32 .

Almost half of the households in 2006 were married couple households, the highest proportion among the English regions. The second most prevalent household type was one-person households comprising 30 per cent of households. This was lower than the level for England as a whole and at regional level only the East Midlands had a lower proportion. Around 6 per cent of households were lone parent households, compared with 8 per cent for England.

Figure 5.8 shows the projected percentage change in number of households between 2006 and 2026 for all regions. The increase in the East of England is the third highest after the East Midlands and the South West.

The number of households is projected to be around 3.06 million households by 2026 . This is an increase of 29 per cent from 2006, which is greater than the projected increase for England of 24 per cent. (Online table 10.15) This is a faster rate than the projected population increase and so the average household size in the region is anticipated to decrease to 2.17 people. The main reason for this is that the number of one person households is projected to increase by 58 per cent between 2006 and 2026, and will become almost equal to the number of married-couple households which is not projected to change, as shown in Figure 5.7. The increase in one person households is partly the result of a continuation of past trends in household composition and partly related to the projected change in age distribution of the population discussed in the previous section. For example, an increase in the proportion of elderly people in the region by 2026 could contribute to an increase in the number of people living alone.

\section{Figure 5.8 Projected increase ${ }^{1}$ in households between 2006 and 2026, by region}

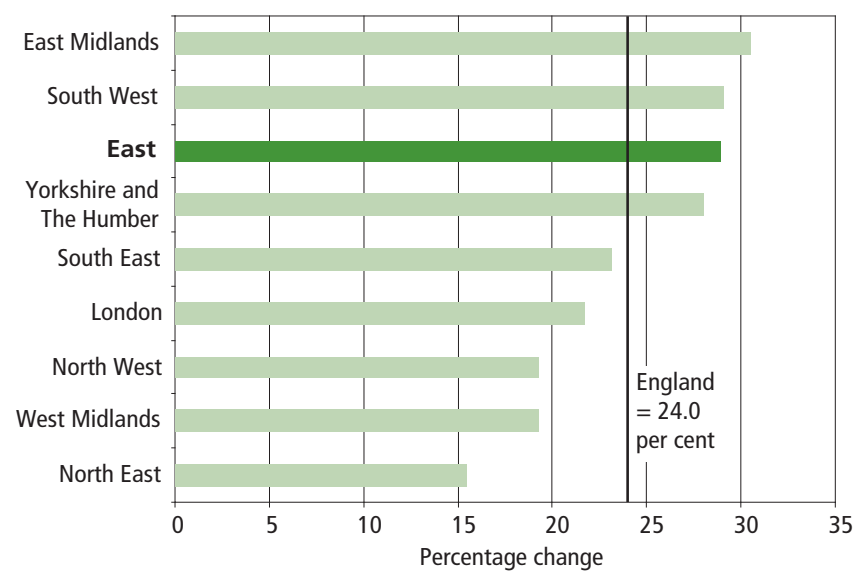

1 2006-based household projections.

Source: Communities and Local Government 
Figure 5.9 Housebuilding: completions by tenure, by region and country, 2006/07

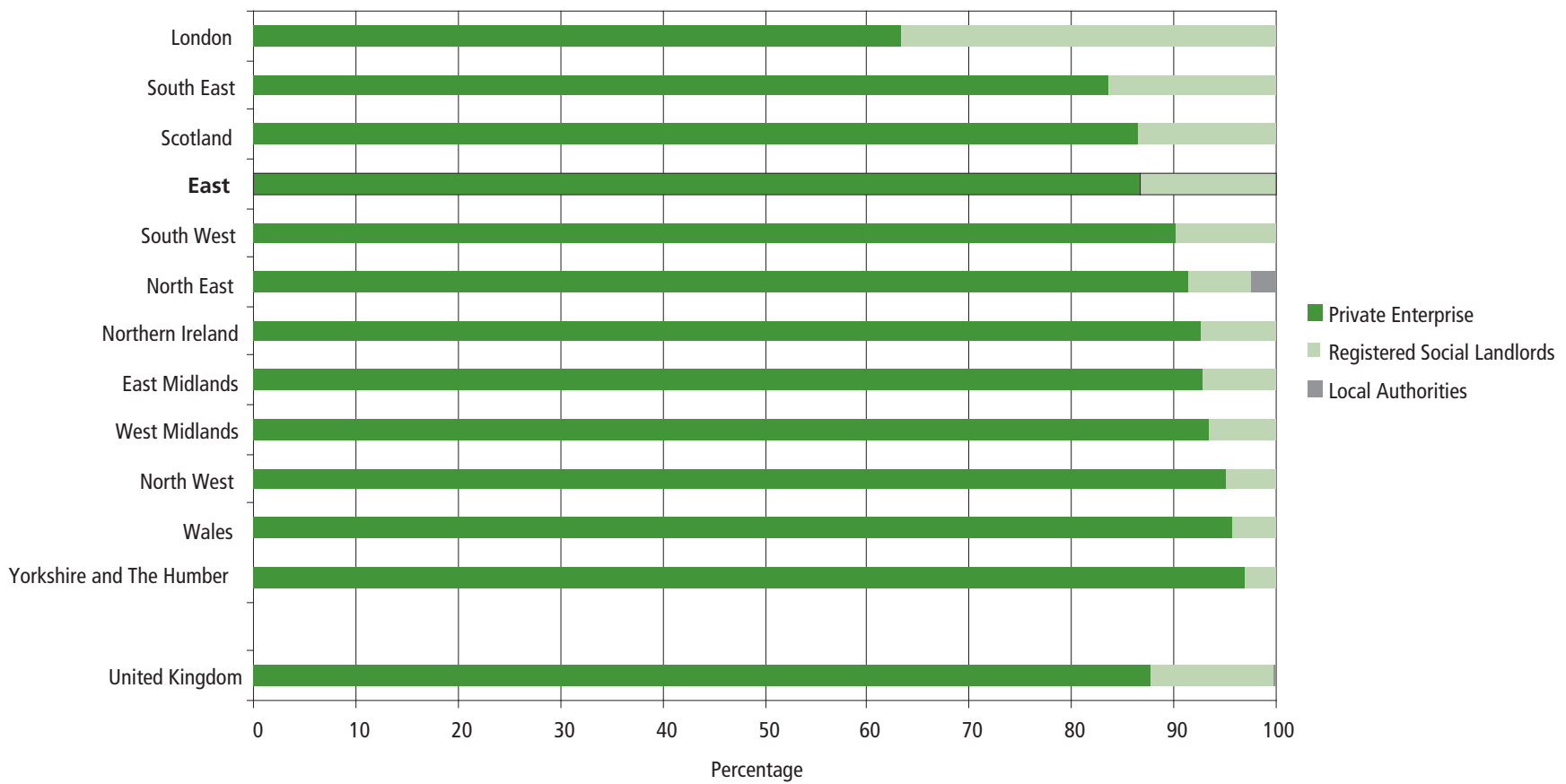

Source: Communities and Local Government; Welsh Assembly Government; Scottish Government; Department for Social Development, Northern Ireland

On 1 April 2007 the East of England had a stock of 2.44 million dwellings, 9.1 per cent of the UK total. This is an increase of 4.8 per cent since 1 April 2002 compared with an increase of 4.0 per cent in the UK overall. (Online table 7.1)

Around 23,000 new permanent dwellings were completed in 2006/07 - 10 per cent of total housing completions in the UK. (Online table 7.2)

Figure 5.9 shows new build completions by tenure for each region in 2006/07. The majority in all regions were for the private sector. In the East of England 13 per cent of housing completions were for registered social landlords, slightly above the UK average of 12 per cent and the third largest proportion in England behind London and the South East. (Online table 7.2)

Land Registry data show the average dwelling price in the region in the fourth quarter of 2007 was $£ 234,000$, above the England average of $£ 216,000$. This was the fourth highest of the regions below London, the South East and the South West. The comparatively high average dwelling price suggests the region is a desirable place to live, although the average dwelling price by local authority ranged from the highest, $£ 393,000$ in St Albans, Hertfordshire, to the lowest, $£ 159,000$ in Great Yarmouth, Norfolk. (Online table 7.4). Recent changes in the housing market are known to have decreased the average dwelling price in the region, although not so much as in some other regions, so data for 2008 onwards may show the East in a different position compared to the national average.

\section{Education and training}

Educational achievement by pupils at the end of Key Stage 4 in maintained schools in the East of England is close to the average for England. In 2007/08, 64.7 per cent of pupils achieved five $A^{*}-C$ grades at GCSE level (or equivalent level 2 qualifications) compared with 64.5 per cent in England (Online table 4.8).

In 2007, 12 per cent of the residents aged between 19 and state pension age in the region had no qualifications, close to the England average of 13 per cent. Around 21 per cent had

\section{Figure 5.10 Resident population aged between 19-59/64 with qualifications below level 2, ${ }^{1}$ by region, 2007}

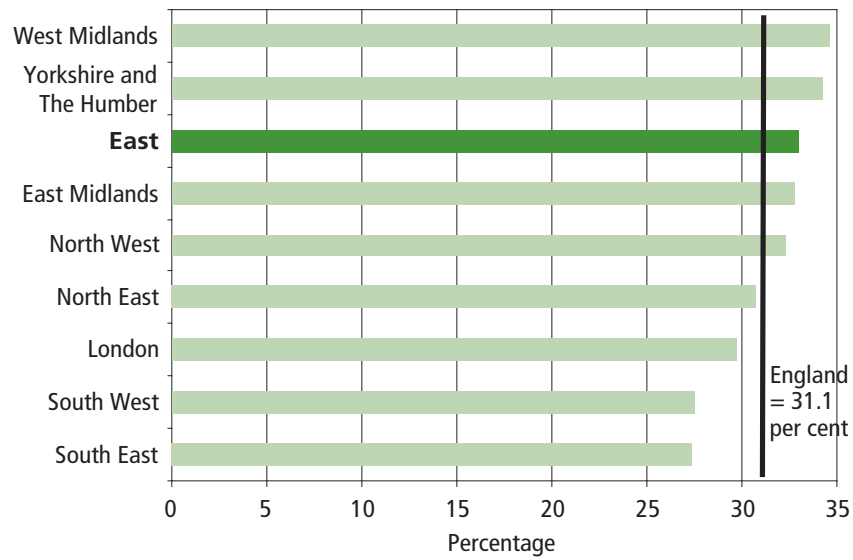

1 No qualification or qualification below level 2. (See Glossary) Source: Annual Population Survey, Office for National Statistics 
qualifications below level 2 only, more than the England average of 19 per cent (see Figure 5.10). At the other extreme, about 28 per cent were qualified to at least level 4;

2 percentage points below the average for the England and also well below the averages for London, the South East and the South West. The older age group in the resident population are much more likely to have no qualifications. In the East over 15 per cent of the economically active aged between 50 and state pension age had no qualifications (slightly higher than in the UK as a whole) compared with about 9 per cent of those aged 16 to 24 and 7 per cent of those aged 25 to 49 .

Participation rates in post-compulsory education and training in the East of England are similar to the average for England. Some 84 per cent of 16 -year-olds, both in the region, and nationally, were in full-time education or governmentsupported training in 2006/07. Among 17-year-olds, the rate falls to 72 per cent, both for the region and England as a whole. (Online table 4.10)

\section{Labour market}

In 2008 the East of England continued to maintain above average rates of employment compared with the UK. In the fourth quarter of 2008, the employment rate for residents of working age was 77.5 per cent compared with 74.2 for the UK: only the South East and the South West regions had higher rates (see Figure 5.11).

The unemployment rate for residents aged 16 and over has remained consistently below the UK average over a long period. In the fourth quarter of 2008 it was 5.5 per cent compared with 6.3 per cent for the UK. This was the fifth lowest rate at regional level, above the South East, South West, Scotland and Northern Ireland.

However, unemployment is much higher in some local areas. For example, modelled unemployment rates for the year ended

\section{Figure 5.11 Working age employment rate, East of England, 1999 to 20081 (seasonally adjusted)}

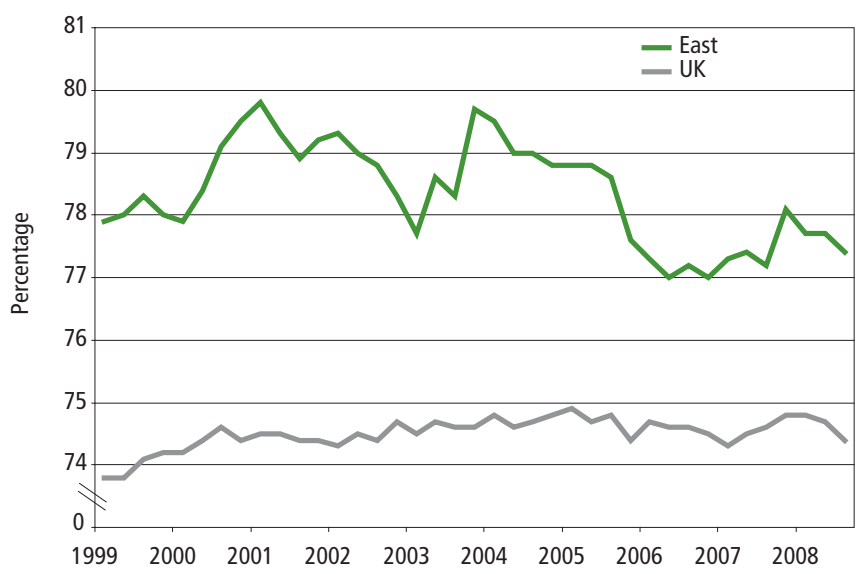

1 Quarterly data to quarter 3, 2008.

Source: Labour Force Survey, Office for National Statistics
March 2008 show Great Yarmouth in Norfolk had an unemployment rate of 7.3 per cent compared with the regional average of 4.2 per cent. The district with the lowest rate in the region was Uttlesford in Essex at 2.4 per cent. (Online table 9.18)

Like the unemployment rate, the claimant count rate for residents aged 18 and over in the region has remained below the UK average for a long period. Between January 2008 and January 2009 it increased from 1.9 per cent to 3.2 per cent but the region maintained its position relative to the UK average. It remains the third lowest region, above the South East and the South West.

In the second quarter of 2008, 19 per cent of working age residents were economically inactive in the East of England, below the UK average of 21 per cent. (Online table 9.15) Looking after family or home, being a student or long term sickness were the main reasons (see Figure 5.12). Between 1992 and 2008 there was a considerable reduction in the percentage of the economically inactive who were looking after their family or home falling from 44 per cent to 32 per cent. Conversely, the proportion who were long-term sick rose from 12 per cent in 1992 to around 20 per cent in 1996 and has remained between 20 and 25 per cent ever since, and the proportion who were students increased from under 20 per cent in 1992 to 24 per cent by 2008.

Median weekly earnings for full-time employees resident in the East of England was $f 499$ in April 2008, above the UK median of $f 479$ and below only London and the South East (see Figure 5.13). Full-time weekly earnings for men are on average $f 126$ more than for women compared with the UK average difference of $\mathrm{f109}$. (Online table 9.19).

People who work in the region earn less than those who live in the region, but may work outside it, as shown in Figure 5.13.

The average (median) employee resident in the East of England earned $\mathrm{f} 31$ per week more than one who worked in the region. This suggests many higher-paid resident workers commute to work outside the region. Apart from London itself, where resident workers on average earn less than the average for all those who work in London, the nearer a region is to London, the greater the commuting effect on income.

Commuting is also evident in the relative regional jobs densities. The East of England has one of the lowest jobs densities of any region at about 0.8 , which means that there are only eight jobs for every ten residents of working age compared with London where there are ten jobs for every ten residents of working age.

Despite the low jobs density, the East of England is one of the larger regions in terms of its number of jobs, having 9.0 per cent of all UK civilian workforce jobs in June 2008, similar to the region's share of the total UK population. This is up slightly from 8.8 per cent in June 1998. The number of civilian workforce jobs increased by 303,000 over this time period, indicating that the workforce in the East has grown at a rate slightly above the UK jobs growth rate. (Online table 9.3) 
Figure 5.12 Reasons for economic inactivity', East of England, 1992 to $2008^{2}$

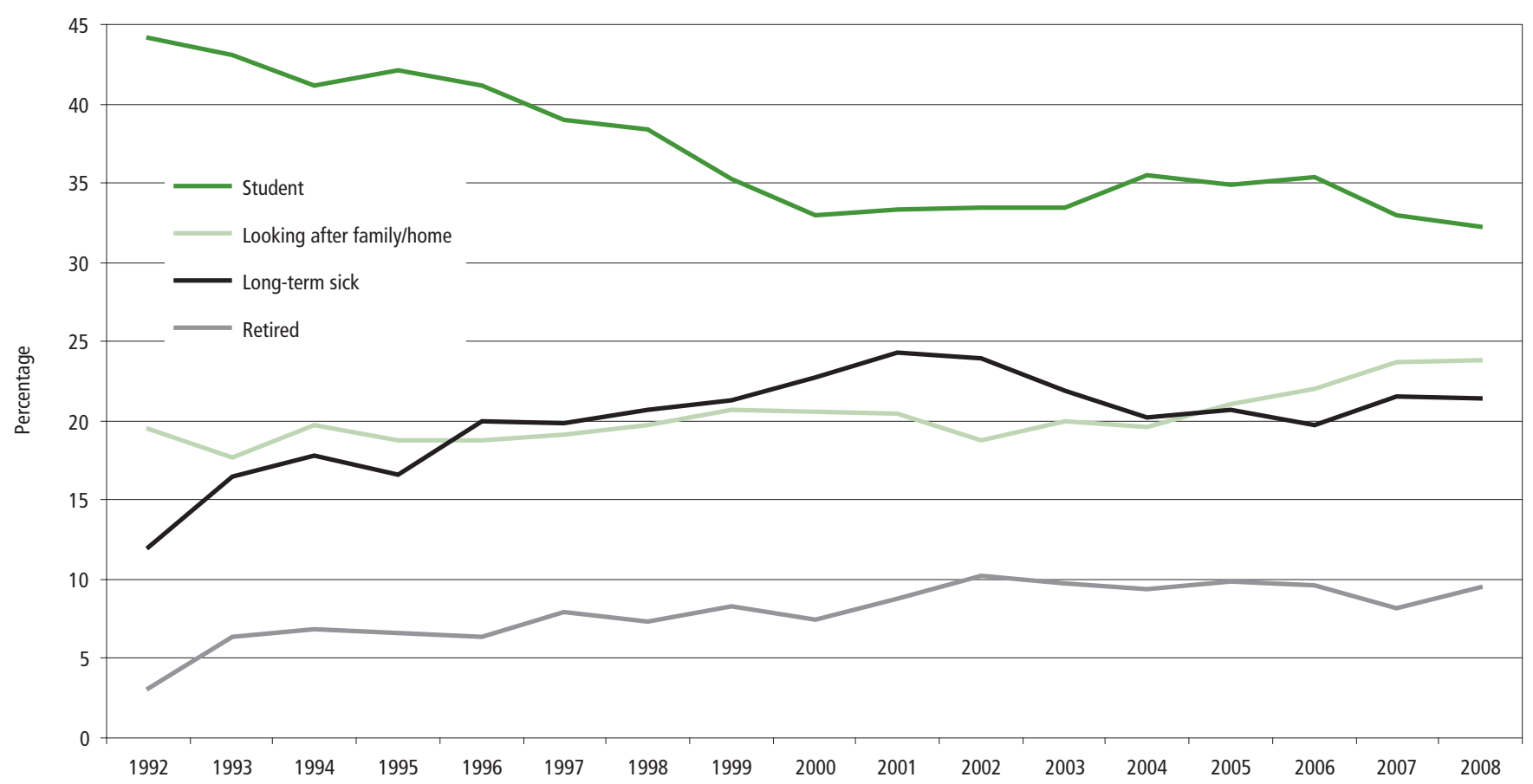

1 As a percentage of inactive working age residents.

2 Second quarter of each year.

Source: Labour Force Survey, Office for National Statistics

Figure 5.13 Median gross weekly pay for residents and in the workplace, by region and country, April 2008

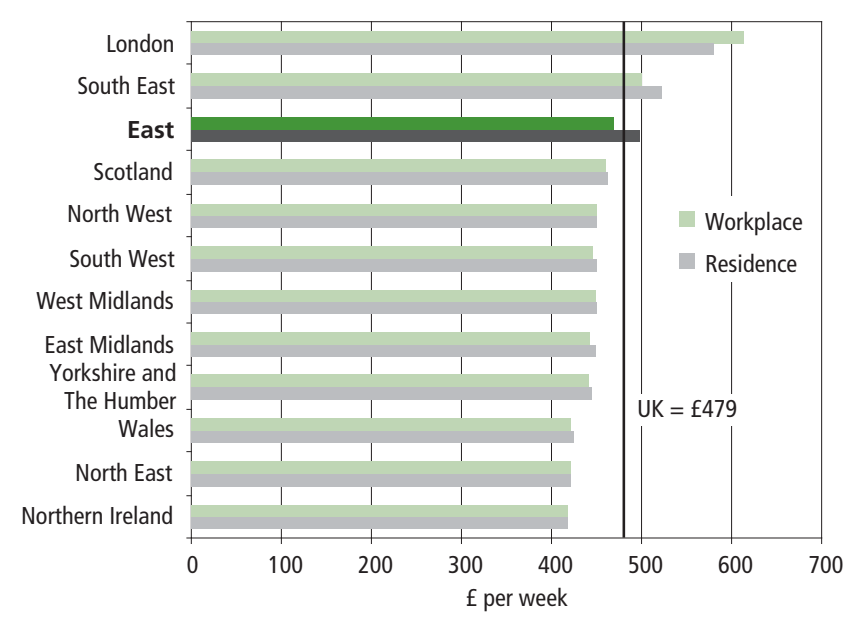

Source: Annual Survey of Hours and Earnings, Office for National Statistics

\section{Economy and industry}

The East of England economy generated $£ 106.8$ billion of gross value added (GVA) on a workplace basis (8.8 per cent of the UK total) in 2007. This represents a below average GVA per head of $£ 18,900$ per resident; although still one of the highest, below only London, the South East and Scotland. (Online table 3.1)
GVA per hour worked, or labour productivity, takes into account employment rates and hours worked along with people working and living in different places. Under this measure the East remains among the highest of the UK countries and English regions. In 2007, GVA per hour worked was close to the UK average ( 0.6 per cent above). Only London and the South East had higher labour productivity. 2007 was the first time since before 1997 that productivity in the region has been above the UK average. (Online table 3.3)

The distribution of GVA within industry sectors in the East of England was broadly similar to that for the UK as a whole, although the wholesale \& retail and construction sectors contributed slightly more and the financial intermediation and public administration sectors slightly less than the national average. Real estate, renting and business activity was the industry contributing most to GVA in 2006, providing 25 per cent of workplace-based GVA, close to the UK average of 24 per cent. Manufacturing contributed 14 per cent of workplace-based GVA, also close to the UK average of 13 per cent. (Online table 3.2)

Despite manufacturing being the second highest contributor to GVA, it only accounted for 11 per cent of employee jobs in December 2007, a noticeable decrease from 1997 when it made up 17 per cent of jobs. (Online table 9.4)

In June 2008, 19 per cent of employee jobs in the East of England were in wholesale and retail trade (see Figure 5.14). This was higher than all other regions and countries of the UK 


\section{Box 1 Measuring Regional Economic Performance}

When measuring the economic performance of regions or sub-regions, the following should be considered:

Gross Value Added (GVA) is a good measure of the economic output of a region. Estimates of workplace based GVA allocate incomes to the region in which commuters work and so better represent the size of the local economy than estimates of residence based GVA, which allocate incomes to the region in which commuters live.

GVA per head (on a workplace basis), which divides output of those working in a region by everybody living in the region, should not be used as an indicator of either regional productivity or income of residents.
GVA per hour worked and GVA per filled job are the preferred measures of productivity of an area.

Gross Disposable Household Income (GDHI) per head is a good indicator of the welfare of residents living in a region.

Productivity, Income and Labour Market indicators should be used together to provide a more complete picture of regional and sub-regional economic performance.

For further information, see the National Statistician's article 'Measuring regional economic performance' which can be found at www.statistics.gov.uk/cci/article.asp? ID =2103

\section{Figure 5.14 Employee jobs by selected industries, East of England and the UK, June 2008}

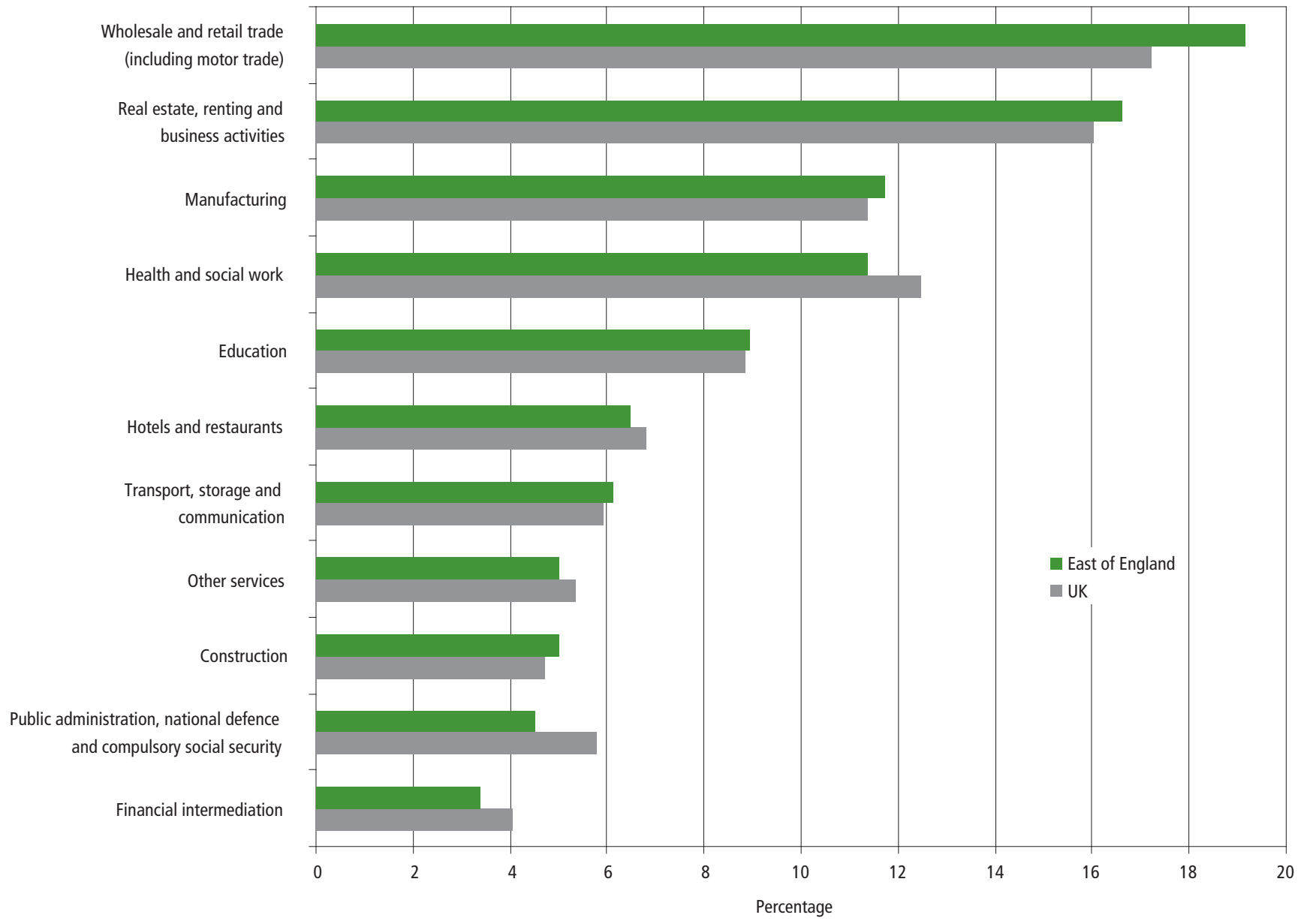


and 2 percentage points greater than the UK average. Real estate, renting and business activities comprised 18 per cent of employee jobs, equal to the UK average. Only London and the South East had a higher proportion of jobs in this sector, which includes research and development and computing activities. Health and Social Work accounted for 12 per cent of jobs. This was close to the UK average of 13 per cent, but was the second lowest proportion, compared with other UK countries and regions, above only London. The East of England had the second lowest proportion of jobs in public administration and defence of all regions (above the South East), 4 per cent compared with 5 per cent in the UK as a whole.

Annual Business Inquiry data show that some local authorities in the East of England have a higher proportion of jobs in manufacturing than the region as a whole. In Babergh, Breckland, Maldon and Waveney, manufacturing employment exceeded 18 per cent of jobs in 2007. Manufacture of food and beverages was below 2 per cent of employment in the region yet it was 6 per cent in Breckland and 8 per cent in Waveney. This could be due to large scale farming operations in these areas, including poultry production. Employment in Financial intermediation was 9 per cent in Ipswich and 12 per cent in Norwich, both well above the regional average or around 3 per cent. This sector includes banking and insurance companies, of which there are several based in these areas. Employment in Retail and wholesale was highest in Thurrock (34 per cent) where Lakeside Shopping Village is located.

During 2007, East of England businesses exported $f 20$ billion of goods, the fourth highest region or country of the UK, and imported $£ 42$ billion, the third highest. The 25 EU countries accounted for 62 per cent of exports from the East of England, and 63 per cent of imports; slightly more than the UK averages of 58 and 54 per cent respectively. Note that import and

\section{Figure 5.15 Business expenditure on research and development as a proportion of gross value added, by region and country, 2007}

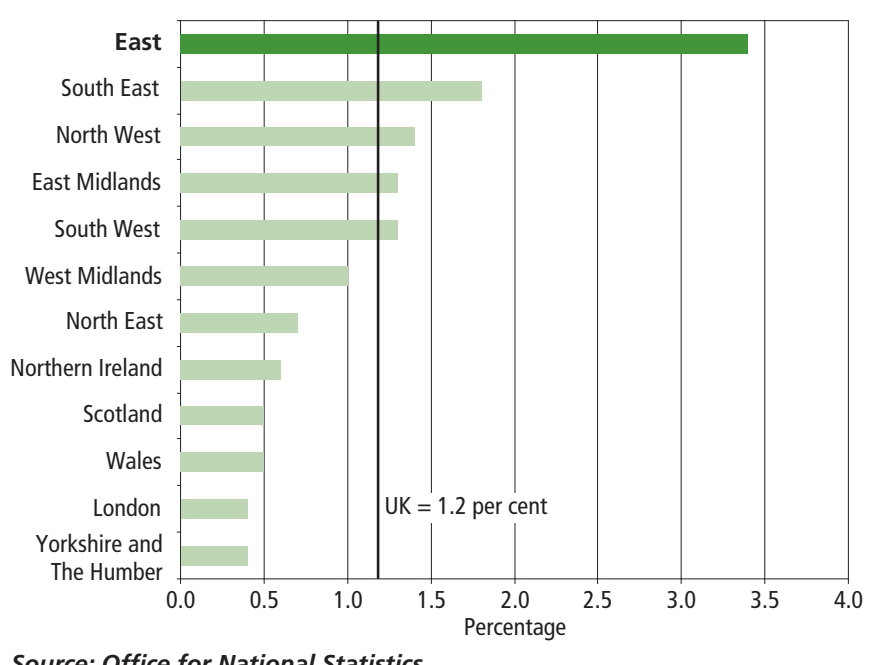

export data may be recorded by head offices, biasing the regional data. (Online table 3.17 )

Expenditure by businesses on research and development (excluding private non-profit sector) in the East of England was $£ 4,350$ million in 2007. This was the highest of all regions and countries of the UK and made up 25 per cent of the UK total. This was 3.4 per cent of workplace based GVA for the region, more than 2 percentage points above the UK average and almost double the figure for the South East, as shown in Figure 5.15. (Online table 3.19)

The high expenditure in on research and development supports the comparatively high employment in the business activities, in which research and development is included.

\section{Disadvantage}

\section{Box 2 Index of Multiple Deprivation 2007}

The Index of Multiple Deprivation (IMD) provides a summary measure of relative deprivation at Lower Layer Super Output Area (LSOA) level in England. The IMD aims to provide a nationally consistent measure of how deprived an area is by identifying the degree to which people are disadvantaged by factors such as low income, unemployment, lack of education, poor health, and crime. Particular points to note:

- not all deprived people live in deprived areas and, conversely, not everyone living in a deprived area is deprived; the indicators identify areas with characteristics associated with deprivation - not deprived people

- the indices should not be used as a measure of affluence. A lack of income deprivation does not necessarily equate to affluence

The indices provide a relative measure of deprivation and therefore cannot be used to determine how much more deprived one LSOA is than another.

This article uses the rankings of all LSOAs in England, which have been divided into five equal sized groups, or quintiles. In England 20 per cent of LSOAs are in the most deprived quintile and 20 per cent in the least deprived quintile and so on. If an area (region or local authority) had the average distribution of deprivation they would have 20 per cent of LSOAs in each quintile.

For more information on the IMD see article on page 93 and the Communities and Local Government website: www.communities.gov.uk/indices

The Index of Multiple Deprivation 2007 shows the variation between the English regions in the overall relative level of deprivation (see Box 2) The East of England had a smaller percentage of Lower Level Super Output Areas (LSOAs) in the 
most deprived quintile in England than any other region apart from the South East. However this masks some variation across the Region. Figure 5.16 shows analysis by county and unitary authority (UA) in the East of England: Cambridgeshire and Hertfordshire had very few LSOAs in the most deprived quintile, while in Luton and Peterborough the proportions of LSOAs in the most deprived quintile were slightly above the national average. Norfolk and Suffolk had below national average proportions of LSOAs in the least deprived quintile but they had higher proportions in the second and third least deprived quintiles than the other counties and UAs in the region.

One measure of deprivation is worklessness. The East of England had a comparatively low proportion of workless households, that are entirely dependent on benefits, 13 per cent in 2007 compared with 16 per cent for the UK. Map 5.17 shows that the areas with the highest percentage of workless households in the region, well above the national average, are North Norfolk and Great Yarmouth. There is similar variation between the regions in the percentage of children under 16 who live in households entirely dependent on benefits. In 2007 the East had a relatively low rate at 12 per cent, compared with the South East which had the lowest rate (10 per cent).

\section{Health}

Figure 5.18 shows the variation in the age-standardised mortality rate for all causes of death between regions in the UK for 2007. The East of England compares well with other regions, ranking third lowest with a rate of 756 per 100,000 residents. This is well below the UK average of 831 per 100,000 residents.

The age-standardised mortality rate was below the rate for the UK as a whole for every main group of cause of death in 2007. The leading causes of death are the same for the region and the UK, circulatory diseases being the most common cause followed by cancer. (Online table 6.4)

Along with the South West, South East and London, the East of England has higher than the average life expectancy at birth, both for females, at 82.6 years compared with 81.7 for England, and for males, at 78.7 compared with 77.5 for England, for the period 2005 to 2007 shown in Figure 5.19. It should be noted that these figures are calculated using region of death not region at birth.

Within the region, life expectancy at birth for males for 2005 to 2007 is highest for Three Rivers - making it the ninth highest ranking local authority in the United Kingdom.

There is considerable variation in infant mortality rates between regions, although differences between years and areas can be due to the small numbers involved, rather than representing significant changes. Bearing this in mind, the East of England had an infant mortality rate of 4.3 per 1,000 live births in 2007 one of lowest in the UK along with the South East and South West. This follows the pattern the East has experienced for the past decade with one of lowest regional infant mortality rates in the UK. (Online table 6.3)

\section{Figure 5.16 Distribution of LSOA' rankings on the 2007 Index of Multiple Deprivation, by county and unitary authority, East of England}

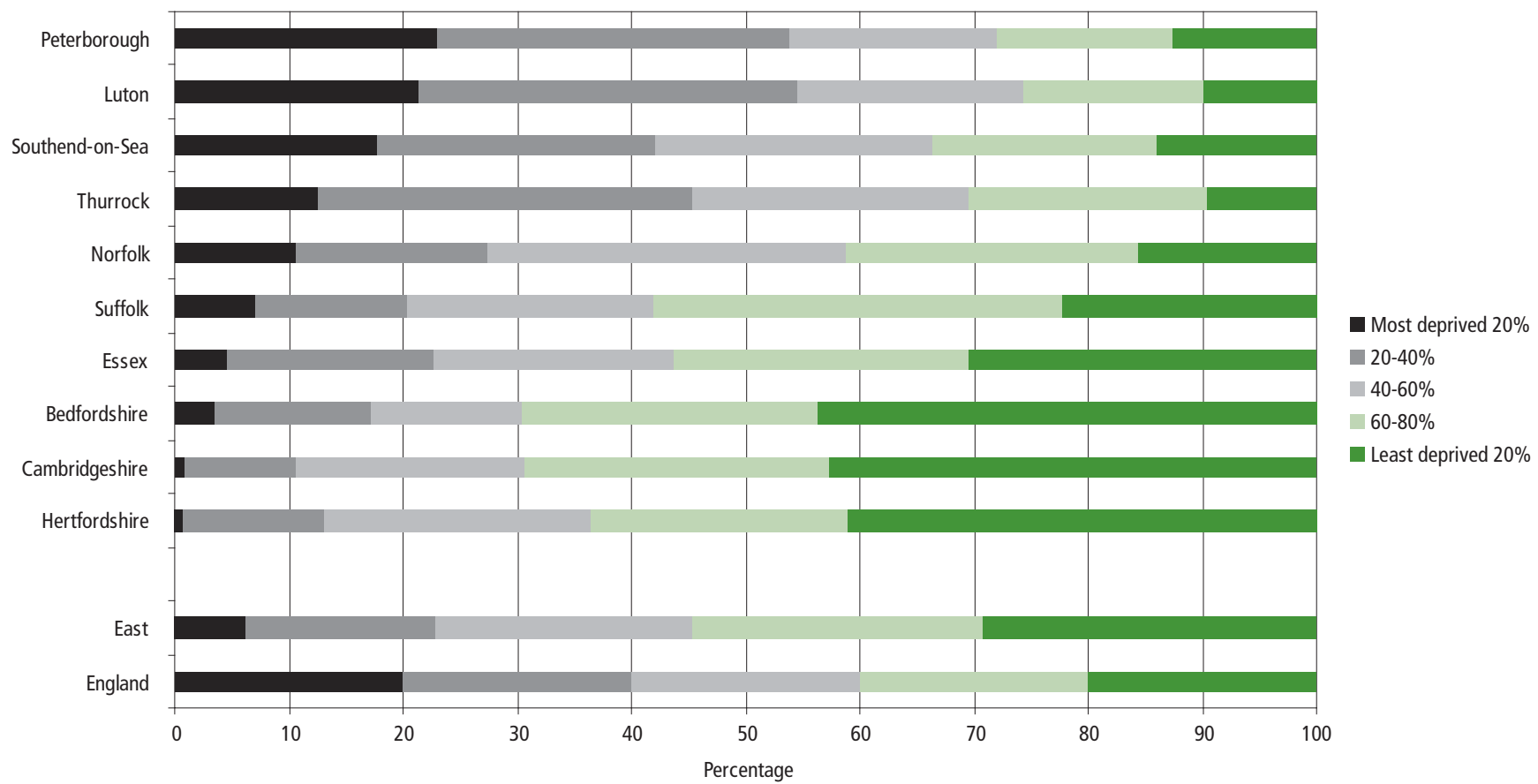

1 Lower Layer Super Output Areas. 
Map 5.17 Percentage of workless households ${ }^{1}$ for East of England by local or unitary authority, 2007

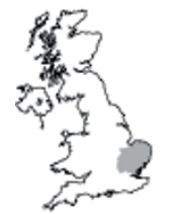

Percentage of households

\begin{tabular}{|l|l|}
\hline & 21.0 or over \\
17.0 to 20.9 \\
13.0 to 16.9 \\
12.9 or under
\end{tabular}
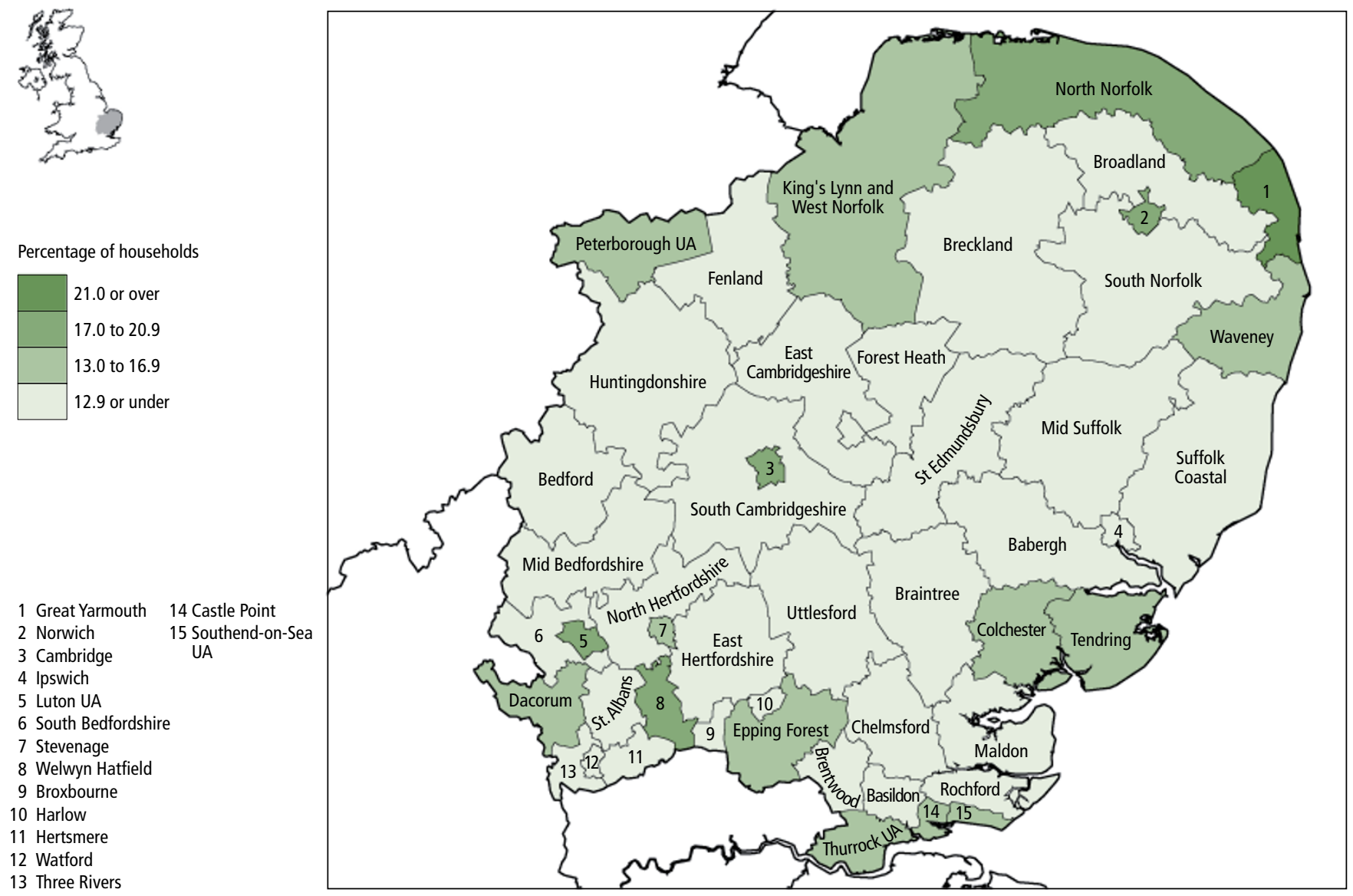

1 A workless household is a working-age household where no one aged 16 or over is in employment. A working-age household includes at least one person of working age (men aged 16-64, women aged 16-59.)

\section{Source: Annual Population Survey household datasets}

Figure 5.18 Age-standardised mortality rate, by region and country, 2007

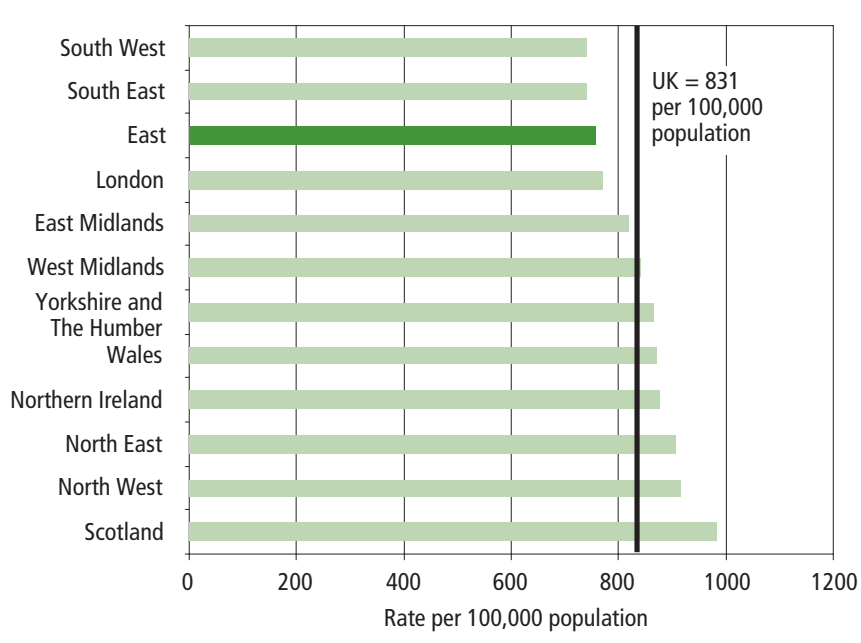

Source: Office for National Statistics
Figure 5.19 Difference in life expectancy at birth between the regions and the England average, 2005 to 2007

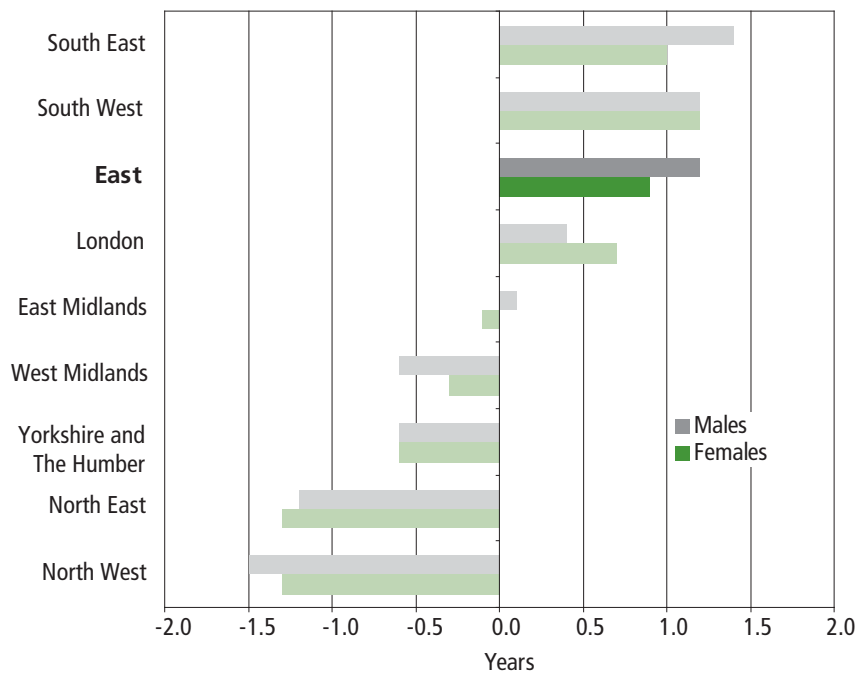

Source: Office for National Statistics 


\section{Figure 5.20 Percentage of live births under} $2.5 \mathrm{~kg}$, by region, 2007

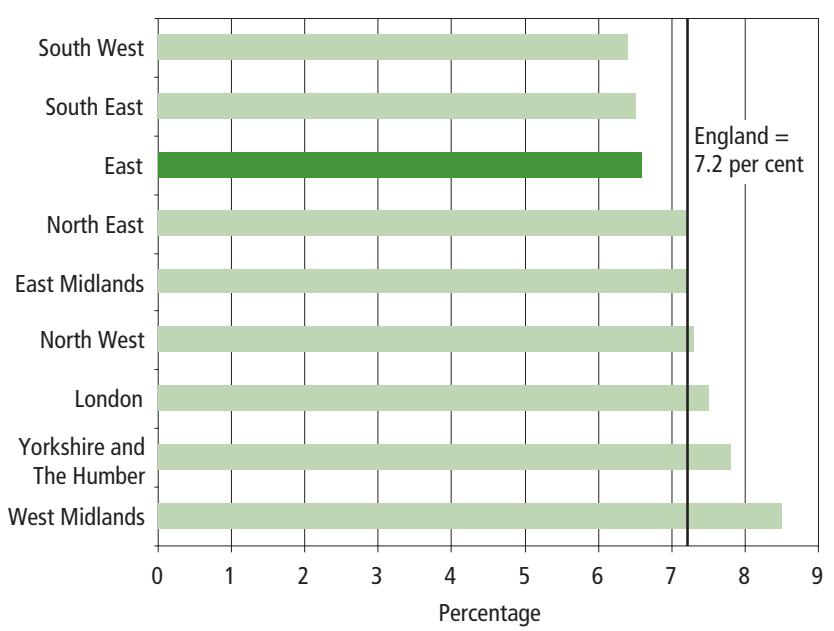

Source: Office for National Statistics

Conception rates in 2006 for women aged under 18 years were among the lowest of all English regions, at 33 per 1,000 women aged 15 to 17. This was a slight fall from the 2001 figure of 34 per 1,000 and followed the national trend for England, which fell from 43 to 41 per 1,000 women aged 15 to 17. This mirrors the below average overall birth rate within the region. (Online table 10.12)

The percentage of births outside marriage has remained relatively stable at a national level over the three years to 2007. However, there are substantial regional and sub-regional variations, with the East one of the lowest of the regions at 42 per cent in 2007 compared with the UK average of 44 per cent. Within the region, Great Yarmouth had the highest proportion of births outside marriage (61 per cent) and St Albans the lowest (23 per cent). (Online table 6.2)

The proportion of low birth-weight babies is considered an important indicator of infant and child health. In 2007 the East of England, at 6.6 per cent, was lower than the English average of 7.2 per cent (see Figure 5.20) but within the region this varies. Watford and Luton experienced the highest levels in 2007 (8.4 and 8.2 per cent respectively). Recent research ${ }^{1}$ found lower birthweights among ethnic groups from the Indian subcontinent. This may be one of a number of possible factors contributing to local level variation in specific areas, such as Luton. In contrast, Uttlesford and Broadland had the lowest proportions of low birthweight babies within the region (3.9 and 4.5 per cent respectively) (Online table 6.2).

\section{Transport}

The average distance travelled per person per year in the East of England by all modes of transport during 2005-06 was

1 Recent research (Moser, Stanfield and Leon (2008), Birthweight and gestational age by ethnic group, England and Wales, 2005: introducing new data on births, Health Statistics Quarterly 39, pages 22-31) suggests that birthweight and ethnic group may be associated, with lower birthweights amongst groups from the Indian subcontinent.
8,260 miles, higher than all other regions except the South East and 15 per cent more than the Great Britain average. (Online table 11.4)

Travel in cars and other private road vehicles comprised 6,970 miles, or 84 per cent of travel by all modes. Rail travel made up nearly 9 per cent of travel; together with the South East this was higher than all regions except London.

The average daily vehicle flow on the region's motorways was 88,200 in 2007, above the England average of 82,500 and well above the Great Britain average of 77,500. This is the fourth highest motorway flow below London, the South East and the East Midlands. However the average daily flow for all roads is one of the lowest at 3,900, below the England average of 4,000 but slightly above the average for Great Britain of 3,500. (Online table 11.11). The motorways that pass through the region, the $\mathrm{M} 1$, the $\mathrm{M} 11$ and the $\mathrm{A} 1(\mathrm{M})$ are all used to access London from the north of England and the Midlands which could account for the above average traffic flow; part of the M25, which surrounds London, also passes through the south of the region.

The usual method of travel to work for 74 per cent of East of England residents in 2007 was by car, van or minibus (see Figure 5.21). This is above the England average of 69 per cent and higher than four other English regions, London, the North East, the South East and Yorkshire and the Humber. Around 8 per cent of residents go to work by rail, higher than any other region bar London, while only 3 per cent use buses and coaches, lowest of all the regions. (Online table 11.7) The high proportion of people travelling to work by train could be largely due to people travelling to London to work.

The proportion of five to 16 year-olds resident in the region who walked to school in 2005/06 was 46 per cent, the same as the average for Great Britain. The proportion going to school in cars was 30 per cent, close to the Great Britain average of 31 per cent. (Online table 11.8)

The average journey distance to school was 2.1 miles for five to ten year-olds, higher than all other regions of England and well above the average for Great Britain of 1.5 miles. For 11 to 16 year olds it was 3.2 miles, the same as for Great Britain as a whole.

\section{Environment}

The original Anglian region designated by the National Rivers Authority had a long term average annual rainfall of just under 600 millimetres between 1961 and 1990, the lowest of any region and just over half the UK average of 1,080 $\mathrm{mm}$. (Online table 5.1) The average rainfall in 2006 was 3 per cent higher than this although it was still the lowest of all regions.

The region has 300 square $\mathrm{km}$ of land in National Parks, accounting for 2 per cent of the region and only 1 per cent of all UK National Park land. Only 6 per cent of East of England land is in Areas of Outstanding Natural Beauty, compared with 13 per cent for the UK. This is less than all regions and 
Figure 5.21 Usual method of travel to work by region or country' ${ }^{1}$ of residence ${ }^{2}$, fourth quarter 2007

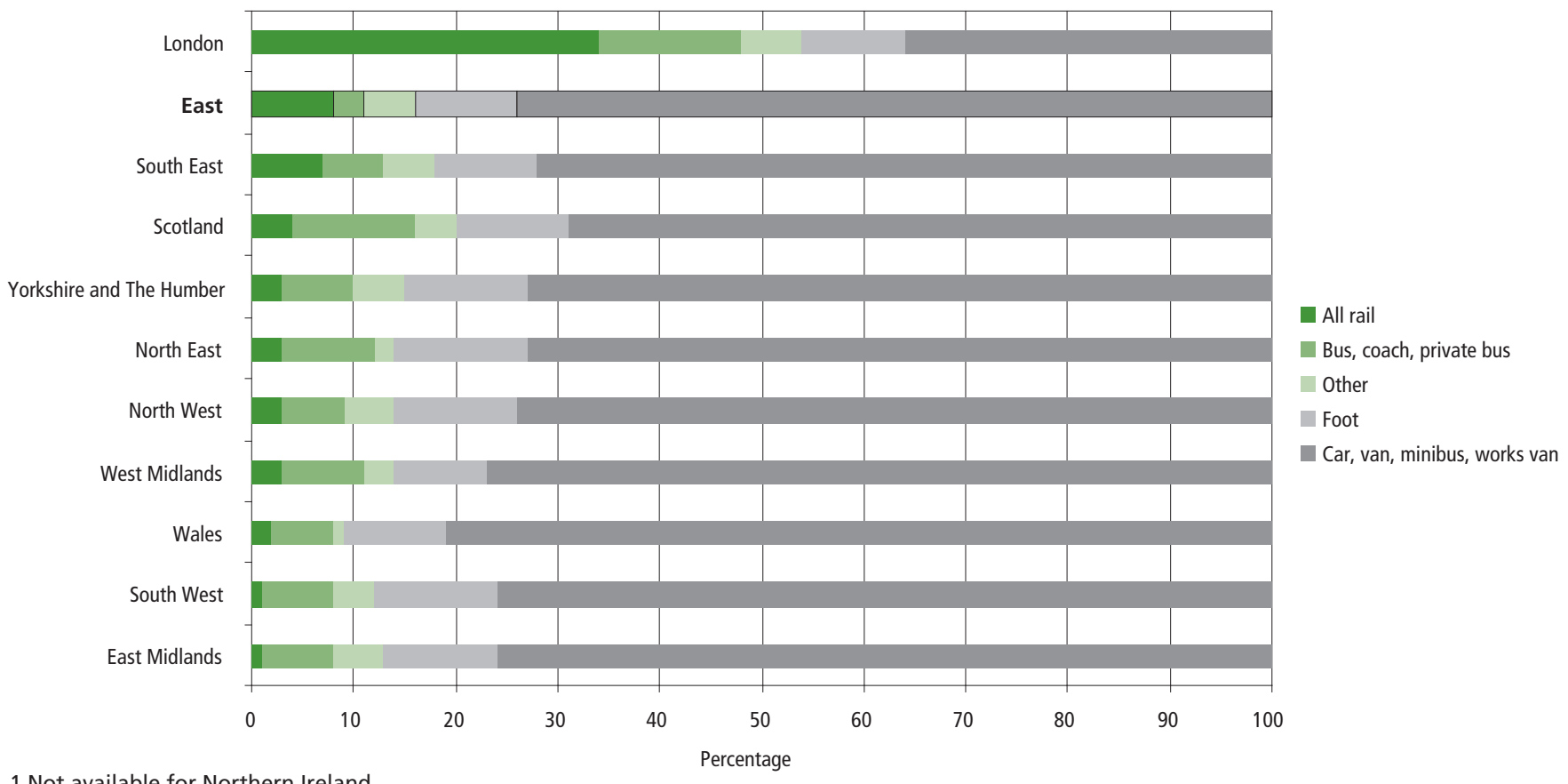

1 Not available for Northern Ireland.

2 Arranged in order of rail usage.

Source: Labour Force Survey, Office for National Statistics

countries of the UK except Yorkshire and The Humber, Wales and the East Midlands. (Online table 5.8)

The region has a relatively small carbon footprint with emissions estimated at 8.1 tonnes per head in 2006, below the UK average of 8.8 tonnes (see Map 9.9 on page 152). This is the third lowest of the English regions with only London and

\section{Figure 5.22 Proportion of household waste recycled and composted for selected regions, 2002/03 to 2006/07}

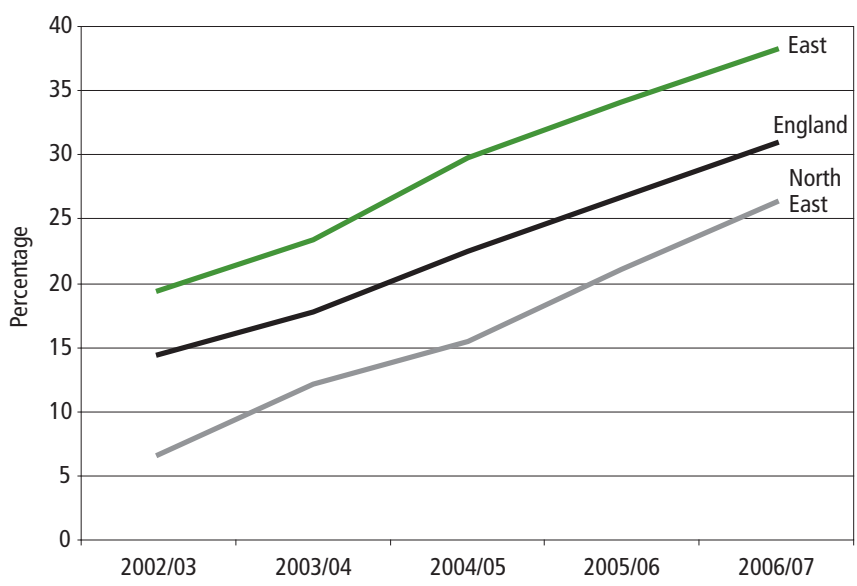

Source: Department for Environment, Food and Rural Affairs
South East emitting fewer tonnes. Of the carbon dioxide emitted in the region 37 per cent came from industrial and commercial sources, compared with 46 per cent in the UK as a whole. This could be partly due to a greater focus on business and financial services and wholesale and retail rather than manufacturing, compared with other regions.

Residents recycle and compost more of their household waste than in any other region in England and have done since 2003/04. In 2006/07, 38 per cent of all household waste produced in the East of England was recycled or composted, compared with the England average of 31 per cent. (Online table 5.11) The region's figure has almost doubled since 2002/03 when 19 per cent was recycled or composted (see Figure 5.22). Of the $471 \mathrm{~kg}$ of recycled waste per household in the region, $192 \mathrm{~kg}$ were composted, more than any other region. Other materials made up $126 \mathrm{~kg}$ per household, also higher than all other regions; this includes co-mingled recycling collections which are common practice in the East of England. (Online table 5.12)

\section{Crime and justice}

The East of England has a comparatively low number of crimes committed against households, as estimated by the British Crime Survey. In 2007/08 there were 2,400 household offences per 10,000 households compared with 2,700 for England and Wales, only the South West had a lower rate as shown in Figure 5.23. Of these household offences, 43 per 
Figure 5.23 Crimes committed against households: by type and region or country ${ }^{1}, 2007 / 08$

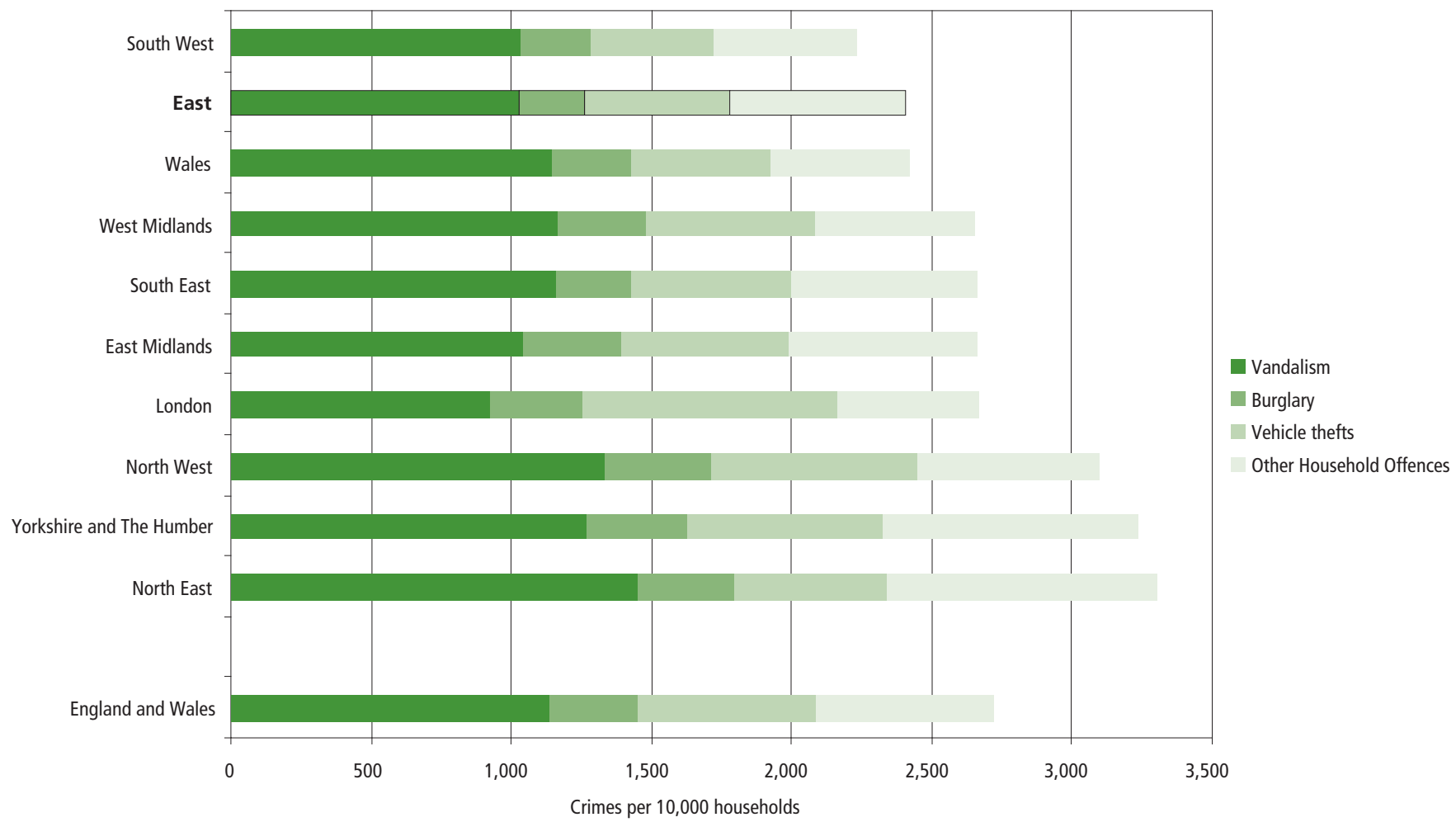

1 Comparable figures are not available for Scotland and Northern Ireland.

Source: British Crime Survey, Home Office

cent were vandalism, close to the England and Wales average of 42 per cent. There were an estimated 230 burglary offences per 10,000 households in the East, which was the lowest rate of any region and well below the England and Wales average of 310. (Online table 2.1)

The rate of crimes committed against persons has a similarly low level in the region. In 2007/08 there were an estimated 730 personal offences per 10,000 residents compared with 850 for England and Wales; only the South West had a lower rate. (Online table 2.2)

The East has the lowest recorded crime rate in England and Wales. The total recorded crime rate in 2007/08 was almost 7,500 per 100,000 population compared with the England and Wales average of 9,100. The most common type of crime was Other theft offences (24 per cent) followed by criminal damage (23 per cent). (Online table 2.3 )

Looking at detection rates (the ratio of offences cleared up, to offences recorded), the East of England was above average for all crime types except burglary, where 12 per cent of crimes were detected - close to the average of 13 per cent for England and Wales. Detection of violence against the person was high with 57 per cent of reported crimes being cleared up compared with 49 per cent for England and Wales; only the North East had a higher rate. Other detection rates varied from 95 per cent for drugs offences to 12 per cent for offences against vehicles. (Online table 2.5 )
The East of England had the fifth lowest rate of people found guilty of offences and sentenced in 2007; 127,000 people aged 18 or over were sentenced, which was 29 per 1,000 adult residents. Only the South East, the South West, the East Midlands and Northern Ireland had lower rates. (Online table 2.10)

Around three-quarters of those sentenced were fined - 73 per cent of men and 80 per cent of women - both close to the England and Wales averages of 68 and 79 per cent respectively. Other sentence types were used with similar prevalence to their England and Wales averages; community penalties were the next most common at 10 per cent for men and 8 per cent for women. Immediate custodial sentences comprised 7 per cent of outcomes for men and 3 per cent for women, making a total of 7,900 immediate custodial sentences.

East of England courts issued 191 Anti-Social Behaviour Orders in 2006 or 34 per million residents; below the England average of 49 per million residents and lower than all regions except the South East and the South West. (Online table 2.6)

The March 2008 police service strength of 11,000 officers on ordinary duty corresponded to one officer to 513 residents. This was the highest ratio of residents to officers of all the regions and countries of the UK and was 35 per cent more than the England average of 380 . However 164 special constables per 1,000 police officers was higher than other regions. (Online table 2.13 ) 